\title{
O complexo de Édipo e a função fálica: sobre a criação de filhos por casais homoparentais
}

\author{
The Oedipus complex and the phallic function: about the raise of children by \\ homoparental couple
}

\author{
Marco Antonio Coutinho Jorge* \\ Luciana Marques **
}

\begin{abstract}
Resumo
No presente artigo, pretendemos examinar a função da castração como orientadora para a escolha do sexo. Detidos na metáfora paterna e seus efeitos, propomo-nos analisar as funções simbólica e imaginária do falo, com a finalidade de desmistificar a promoção, ainda corrente, de premissas normativas que não só caminham na direção da preleção complementar dos sexos, como difundem no imaginário social questões que aludem à importância do sexo dos genitores nas funções familiares e aos riscos inerentes à falta de um indicador da distinção anatômica dos sexos em crianças criadas por casais homossexuais. Em contraponto ao discurso moral corrente, apresentamos a importância do pai em sua função de Lei e da mãe como estatuto de tesouro do significante para o infans, ambos desligados de qualquer distinção anatômica necessária à assunção de um sujeito de desejo.

Palavras-chave: SEXUALIDADE; HOMOSSEXUALIDADE, COMPLEXO DE ÉDIPO; FALO; CASTRAÇÃO.
\end{abstract}

\begin{abstract}
In this article we intend to examine the function of the castration as a guide to the choice of the sex. Halted in the paternal metaphor and its effects, we propose to analyze the symbolic and imaginary functions of the phallus. We intend to demystify the still strong promotion of normative premises that do not only walk towards the discourse of the complementarity of sex but also disseminate in the social imaginary matters that mention the importance of the genitor's sex in the familiar functions and the inherent risks, due to the lack of a anatomic sex indicator, in children raised by homosexual couples. To oppose the current moral speech, we show the importance of the father in the function of Law and the mother's as a status of treasure of the significant to the infans, both shut from any necessary anatomic distinction to the assumption of a subject of desire.
\end{abstract}

Keywords: SEXUALITY; HOMOSEXUALITY; OEDIPUS COMOLEX; PHALLUS; CASTRATION.

\footnotetext{
* Médico Psiquiatra, Doutor pela UFRJ, Professor Associado do Instituto de Psicologia da UERJ, Procientista da UERJ, Psicanalista Fundador e Diretor do Corpo Freudiano Escola de Psicanálise Seção Rio de Janeiro.

Endereço: Rua Terezina, No 19 - Santa Tereza, Rio de Janeiro - RJ. E-mail: macjorge @ corpofreudiano.com.br. Tel.: (21) 2242.5237 | (21) 98101.2473.

** Psicanalista, Doutora pela UERJ, Professora e Supervisora Clínica da Graduação em Psicologia e da PósGraduação em Teoria Psicanalítica e Prática Clínico-Institucional da UVA.

Endereço: Av. Tim Maia, No 7.495, Apt ${ }^{\circ}$ 404, Bl. Geribá - Recreio dos Bandeirantes, Rio de Janeiro - RJ. E-mail: lrmarques@ live.com. Tel.: (21) 3344.4951 | (21) 99965.7729.
} 
Ao inaugurar a psicanálise, em 1900, com o texto A interpretação dos sonhos, dedicado ao inconsciente, Freud faz sua primeira referência ao falo e seu primado. Na seção sobre a Figuração por símbolos nos sonhos - outros sonhos típicos, apresenta o fragmento de um sonho descrito em uma carta que Bismarck ${ }^{(1)}$ envia ao Imperador Guilherme I da Alemanha, em 18 de dezembro de 1881.

Nesse sonho, Bismarck cavalgava por uma trilha que se estreitava, impedindo-o de avançar ou recuar. Diante do obstáculo intransponível, golpeia com um chicote a parede da rocha e invoca o nome de Deus. "O chicote cresceu interminavelmente e a muralha rochosa desmoronou [...] abrindo-se um largo caminho [...]" (Freud, 1900-1901/2007, p.382). O ato de golpear com um chicote que crescia de modo interminável tem um "caráter inequivocamente fálico no sonho" (Freud, 1900-1901/2007, p.384), e provém, como salienta Freud, de desejos infantis que, devido aos mecanismos de proteção do sonho, puderam ser realizados com êxito, sem infringir a censura.

Essa primeira referência ao falo, articulada com os desejos infantis, a partir de uma formação do inconsciente - o sonho, no caso aqui citado - já o revela como um operador lógico que não deve ser confundido com o órgão: trata-se de uma representação simbólica, inerente ao mecanismo de distorção do sonho, influenciado pela linguagem do inconsciente.

Essa tese inicial será ratificada por Freud cinco anos depois, em 1905, quando publica Três ensaios da teoria sexual e conclui que a vida sexual da criança já conta com os esboços dos componentes sexuais da pulsão, sendo a sexualidade adulta o resultado da disposição perverso-polimorfa da infância.

Num momento muito precoce, Freud nos diz, o erotismo oral fica em primeiro plano, advindo, em seguida, a predominância do sadismo e do erotismo anal e, "[...] numa terceira fase - que a criança se desenvolve pelo primado do falo - a vida sexual passa a ser comandada pela excitação das zonas genitais propriamente ditas" (Freud, 1905/2008, p. 213).

Conforme Freud acentua, essas manifestações polimorfas da sexualidade, que ganham expressão através da atividade masturbatória das crianças, são as responsáveis por ancorar a teoria sexual infantil de que todos os seres humanos têm pênis. Tal constatação o leva a destacar a universalidade do falo a partir de sua teoria da libido, única, masculina, que se faz representar como fantasia infantil advinda do gozo do órgão.

Essa premissa fálica, indicada em 1905, é retomada ao longo da obra freudiana e gradativamente articulada à origem do complexo de castração. Conforme se verifica três anos depois, no texto Sobre as teorias sexuais infantis, Freud destaca que a primeira teoria sexual infantil deriva do desconhecimento da diferença dos sexos, pois as crianças atribuem a todos, inclusive às mulheres, e mais especificamente à mãe, a posse de um pênis:

O menino, governado, em grande parte, pelas excitações do pênis, procura prazer estimulando-o com a mão. Seus pais, ou as pessoas responsáveis por seu cuidado, the surpreendem e o aterrorizam com a ameaça de que lhe seria cortado o membro. O efeito dessa 'ameaça de castração' é, em seu típico nexo com a estima que se tem por essa parte do corpo, extraordinariamente profundo e duradouro (Freud, 1908/2007, p.193).

Na menina, por sua vez, o clitóris é a sede das excitações, mas Freud nos alerta que, do mesmo modo que no menino, essa zona também confere à atividade sexual seu caráter masculino, confirmando a dose de verdade presente na teoria infantil de que todos têm pênis. Assim, o que vale destacar é que a teoria da universalidade do pênis é prévia à percepção da ausência do pênis nas mulheres.

Interessante notar a ênfase que Freud dá à mãe dentre todas as mulheres, ao suposto pênis da mãe na fantasia infantil, marcando sua potência como mãe fálica, tal como podemos reconhecer nas teorias de Hans e na fantasia de Leonardo Da Vinci. Hans, aos 3 3\%4 anos, já 
afirmava nunca ter visto o 'faz-pipi' de seu pai, mesmo quando este se despia, ao passo que não deixava de observar que, caso sua mãe tivesse um 'faz-pipi', este seria maior do que o de um cavalo. A mesma ênfase na mãe fálica é posta por Leonardo Da Vinci, em sua fantasia sobre o milhafre: "A mãe que amamenta a criança - melhor: em quem a criança mama - foi transformada num milhafre que introduz sua cauda na boca da criança". (Freud, 1910/2007, p.87)

Portanto, embora o falo seja comumente confundido com o órgão peniano, seu suporte imaginário, podemos perceber que ele é apresentado desde o início da obra freudiana como objeto central na economia do desejo, na medida em que a criança o atribui fantasisticamente à mãe, uma vez que é dependente de seu amor e de sua potência.

Partindo dessa primeira premissa, Freud pôde apresentar-nos, finalmente, em 1923, no artigo A organização genital infantil: uma interpolação com a teoria da sexualidade, a castração como a inscrição da falta que é significada pelo falo, significante que nomeia o desejo e confere significação aos objetos como destacáveis:

Me parece, isso sim, que só se pode apreciar corretamente o significado do complexo de castração se considerarmos sua gênese na fase do primado do falo. [...] Com acerto se havia assinalado que a criança adquire a representação de um dano narcísico por perda corporal, sendo a raiz dessa perda o seio materno logo após mamar, a cotidiana deposição das fezes e até mesmo a separação do ventre da mãe ao nascer. Contudo, só cabe falar de um complexo de castração quando essa representação de uma perda estiver enlaçada com os genitais masculinos (Freud, 1923/2007, p.147-148).

Somente quando o pênis ganha o estatuto de destacável do corpo é que ele pode, por operação da linguagem, tornar-se análogo ao seio, perdido no desmame, e ao excremento. Conforme Freud alerta, é preciso estar ciente dessa conexão para orientarmo-nos diante das fantasias inconscientes que, por associação, tratam as fezes, o dinheiro, o bebê e o pênis como se significassem a mesma coisa, representados pelo mesmo símbolo - o falo.

Somente a partir da falta fálica - emergindo no campo materno e, consequentemente, resvalando na criança -, é que a diferença dos sexos ganha expressão pela primeira vez. Ou seja, é na medida em que o falo falta que pode ser definido como falo simbólico, ponto em que a dissolução edípica ganha destinos distintos para os meninos e para as meninas.

Foi através dessa constatação que Freud se dirigiu - primeiramente em 1910, e depois em 1927 - à investigação do fetiche, como substituto do falo que falta à mãe, subsistindo como proteção do sujeito que, visando preservá-lo, escolhe como fetiche uma parte do corpo ou um objeto que possa simbolizar o pênis faltoso.

Coloca-se aqui uma questão: como dizer que uma mulher seria privada de um órgão que, por natureza, ela não tem? Essa afirmação só é possível por tratar-se de um objeto simbólico que a linguagem impõe, objeto sempre faltoso, na medida em que ele falta primeiramente à mãe, por onde o desejo da criança é despertado ${ }^{(2)}$.

Assim, vale esclarecer que o fetiche não é o substituto de um pênis qualquer, mas de um pênis determinado, que tem grande importância na vida infantil, embora seja perdido mais tarde: "Para dizê-lo com maior clareza: o fetiche é o substituto do falo da mulher (da mãe), no qual o menino acreditou e ao qual não deseja renunciar - sabemos por quê" (Freud, 1927/2007, p.148).

Notemos que a ênfase recai, novamente, sobre a mãe, uma vez que, como ressalta Lacan, ao real do corpo da mulher nada falta. Desse modo, o que a instauração de um fetiche visa preencher é a imagem fálica atribuída à mãe, advinda da fantasia infantil. Logo, o fetiche não é um substituto do pênis - que além de as mulheres não terem, tampouco lhes falta -, mas sim do falo materno, tal como Freud fez questão de destacar. 
Esse breve prefácio servirá de guia para trilharmos os caminhos do inconsciente que revelam o complexo de Édipo, e introduzirmos as questões deste artigo. Nesse ponto, será proposto pensar as diferentes funções, materna e paterna, em sua independência dos aspectos anatômicos: poderia o Édipo assumir função normativa para o sujeito quando não há uma mulher assumindo a função materna? O que resvala no sujeito quanto à assunção de seu sexo, quando um homem exerce essa função? Qual a relação entre a transmissão da Lei e a anatomia do agente da função paterna?

É importante lembrar que as descobertas freudianas revelam que, para ambos os sexos, apenas o falo entra em consideração como significante articulador da estrutura simbólica e sexual, por onde o desejo da criança é despertado pelo objeto de desejo do Outro.

Ao recorrer-se a Lacan, com o primeiro tempo do Édipo, verifica-se que a mãe deseja na criança sua imagem fálica, devido à falta de objeto dada pela estrutura e transmitida pela linguagem, que funda toda a ordem simbólica, anterior a cada nascimento. É sobre essa falta que o falo - e não o pênis - pode presentificar-se como objeto privilegiado do desejo humano, para homens e mulheres, sendo o próprio motor da relação do sujeito com o mundo.

Em outras palavras, o falo, operando como objeto que falta ao Outro - $\varphi$ minúsculo -, orienta metonimicamente a identificação imaginária do filho como falo, lugar de objeto que a criança ocupa buscando satisfazer o desejo da mãe. É assim que o bebê encontra uma brecha e se oferece, com todo o seu corpo, como objeto fálico que se presta a tamponar essa fenda.

No entanto, embora a criança, por seu desamparo original, escolha forçosamente se assujeitar aos caprichos maternos, vale notar, para que essa metonímia seja possível, que o pai real $^{(3)}$, pai na qualidade de procriador, situado no nível simbólico devido a uma necessidade da cadeia significante, já está aí, conferindo seu nome, nome de pai, mesmo que para a criança ainda permaneça velado:

O pai, para nós, é, ele é real. [...] uma mulher não engravida se não houver praticado o coito, e também num prazo muito preciso. [...] O importante, com efeito, não é as pessoas saberem perfeitamente que uma mulher só pode engravidar quando pratica um coito, mas sancionarem num significante que aquele com quem ela praticou o coito é o pai (Lacan, 1958/1999, p.186-187).

Essa mítica completude fálica já ratifica a elaboração freudiana de que "[...] não há, portanto, uma primazia genital, mas sim uma primazia do falo" (Freud, 1923/2007, p.146), pois a posição do significante paterno, no plano simbólico, antecede e funda a captura imaginária - ponto nodal que nos conduz à linguagem, à ênfase que recai sobre o significante na economia do desejo.

Desse modo, a mãe, como trazido por Freud, ou o tesouro dos significantes, como introduzido por Lacan, é uma função que só promove o estatuto de Outro primordial a quem é representante desse lugar para o bebê devido a um efeito de linguagem e não através de um dado que, a priori, se apresente pela via anatômica. Ou seja, não se trata de qualquer espécie de instinto materno nas mulheres. Igualmente, o pai é um semblant, capaz de promover um efeito metafórico ao substituir o desejo enigmático do Outro pelo Nome-do-Pai, uma vez que o pai é simbólico e só existe por uma construção mítica, Um-pai que funda a posição da Lei.

Sendo assim, o humano, ser de linguagem, desamparado por estrutura, precisa que alguém, e não necessariamente uma mulher, o acolha e entenda seu apelo como uma intenção dirigida, uma mensagem. Cabe, a quem por desejo exerce essa função, transformar o apelo da criança em significante, trazendo o sentido: fome, sede, dor, calor, frio, etc. Por outro lado, o pai, revestido como símbolo, aquele que é suposto ter o que a mãe deseja, não precisa estar presente no ambiente para se fazer presente no complexo, dando acesso à Lei. Estes são os dois pontos que precisam ficar claros, a fim de que possamos pensar o complexo de Édipo e de castração como operações de linguagem, essencialmente simbólicas. 
Esse percurso se inicia com o tempo zero, onde o significante materno é o primeiro significante introduzido na simbolização, na medida em que a criança depende do desejo de quem exerce essa função, desenhando, nessa relação, as primeiras realidades com o meio vivo. Aqui, a mãe é uma exigência simbólica, um dado de estrutura que se manifesta pelo par presença-ausência. A mãe, em si, é um símbolo, pois não há constituição do Outro nesse momento, denominado por Freud de autoerótico. Trata-se do puro vaivém do objeto real, o seio, articulando à criança o registro do apelo.

Através dessa primeira simbolização, o infans passará do marco zero ao primeiro tempo do Édipo; ou seja, o desejo da criança irá se configurar como desejo do desejo desse ser primordial, surgindo o Outro, onipotente, agente da frustração, por ser capaz de dar - ou não - acesso aos objetos simbólicos. Aqui, há uma transformação, pois o que era mero objeto da necessidade traz consigo um além, sendo oferecido, ao filho, algo que o objeto em si não comporta, mas que vem atrelado com a resposta que o Outro oferece ao apelo: o dom. O dom é o signo do amor, aquilo que o objeto não tem, mas que é oferecido à criança juntamente com o objeto, levando Lacan a afirmar que amar é dar aquilo que não se tem, é doar a falta, dar uma significação ao vazio original, transmissão da castração:

A partir de seu ingresso na dialética da frustração, o objeto real não é em si mesmo indiferente, mas não tem necessidade alguma de ser específico. Mesmo que não seja o seio da mãe, nem por isso ele perderá algo do valor de seu lugar na dialética sexual, de onde se origina a erotização da zona oral. Não é o objeto que desempenha, em seu interior, o papel essencial, mas o fato de que a atividade assumiu uma função erotizada no plano do desejo, o qual se ordena na ordem simbólica. (Lacan, 1957/1995, p. 188)

Reside aí toda a particularidade do humano, o que permite perceber que não há qualquer momento simbólico ideal, como uma simultaneidade entre a intenção do bebê, que se manifesta como mensagem ao Outro, e a ratificação exata desse significante no Outro. No humano, ser de linguagem, há um efeito de transformação que faz do sujeito um 'corno', traído pelo fato de seu desejo deitar-se com o significante: [...] a partir do momento em que se fala com alguém, existe um Outro, um Outro em si, como sujeito do código, e já nos encontramos submetidos à dialética de "corneação" do desejo (Lacan, 1958/1999, p. 155).

A passagem do desejo pela cadeia significante é o que faz com que tudo dependa do Outro, como lugar do código que, por si só, traz a modificação do desejo por sua transposição ao nível da linguagem. Daí qualquer satisfação possível do desejo depender da articulação entre a invocação, o apelo do bebê, e a resposta vinda da sede do código, do qual o grito retorna modelado, articulado como palavra, ratificando que "desde a origem, a criança se alimenta tanto de palavras quanto de pão, e perece por palavras" (Lacan, 1957/1995, p. 193).

Notemos que não se trata de um dado objetivo, mas de uma articulação do sujeito no nível da demanda, no qual os objetos que o infans quer reter consigo não são apenas objetos da satisfação, mas objetos do dom, que testemunham a potência materna - que pode, ou não, responder ao apelo -, marcando o seu valor. A partir de então, "o que conta, vocês vão ver, são as carências, as decepções, que afetam a onipotência materna" (Lacan, 1956/1995, p. 70). Nesse momento da dialética, os objetos tornaram-se simbólicos, não importando se a mãe traz o seio, a mamadeira ou a chupeta, pois o que vale é que tenha veiculado o dom, já que a satisfação que está em jogo na dialética da frustração, à qual o bebê faz apelo, é da ordem do amor.

Há, no eixo pulsional, um circuito de trocas, que possibilita a substituição do objeto que deixa de ser do nível da necessidade e passa a ser tomado pela via simbólica -, introduzindo o infans na ordem humana: 
Com efeito, todas as relações com o corpo próprio que se estabelecem por intermédio da relação especular, todas as pertinências do corpo entram em jogo e são transformados por seu advento no significante. O fato de que os excrementos se tornem, durante um certo tempo, o objeto eletivo do dom não deve certamente nos surpreender, já que é, evidentemente, no material que se oferece a ela em relação a seu próprio corpo que a criança pode encontrar o real feito para alimentar o simbólico [grifo nosso]. O fato de que a retenção possa se tornar recusa tampouco deve surpreendê-los (Lacan, 1957/1995, p. 193).

Desde então, a satisfação da necessidade se torna uma parva compensação para a decepção imposta pela ordem simbólica, uma vez que o objeto, quando presente, comporta um fundo de ausência, marcando que o que se deseja não será alcançado, por impossibilidade. A fim de satisfazer o que não pode ser satisfeito, a criança se faz de objeto enganador. $\mathrm{Na}$ tentativa de garantir os objetos de dom, evitando que aquilo que é falta no agente da função materna a leve para outras direções, a criança se oferece para obturá-la, mantendo-a completa, mesmo que ao preço da alienação, pois se trata de uma questão de sobrevivência.

Portanto, para que esse deslocamento seja possível, devemos notar que o Outro - M -, como lugar do significante, traz consigo o reflexo do significante essencial - $\mathrm{P}$-, que conduz o sujeito a entrar no jogo pela via da 'imagem guia' do falo. Essa imagem guia $-\varphi-$, que tanto opera unificando a imagem total do corpo quanto permite ao sujeito uma primeira identificação imaginária, tem sua matriz no significante paterno $-\mathrm{P}-$, por onde surge o efeito da metáfora:

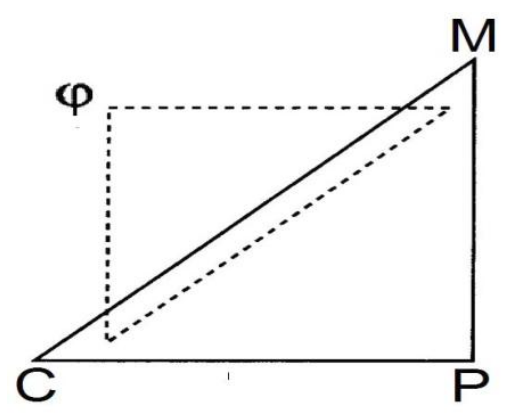

Há nesse desenho uma relação de simetria entre falo, que está aqui no vértice superior do ternário imaginário, e pai, no vértice inferior do ternário simbólico. Veremos que não há aí uma simples simetria, mas uma ligação. Como é que já se faz possível eu adiantar que essa ligação é de ordem metafórica? (Lacan, 1958/1999, p. 189)

É assim que o significante paterno, revestido como símbolo, por sua ligação metafórica ao falo, funda a posição do falo no plano imaginário, mediando o desejo materno e apontando esse mais-além, que permite a identificação da criança com o falo, na medida em que o falo é a resposta para a incógnita suscitada pelo desejo do Outro.

Nessa etapa fálica primitiva, o ponto nodal coloca-se no plano imaginário, na escolha do filho de ser ou não ser o falo, uma vez que já se encontra projetado no plano simbólico que o Outro não o tem. A essência desse momento reside no resultado, pois é o que a criança consegue pescar; ou seja, o pai, seja quem for, ainda está velado para ela, mas a metáfora paterna opera por si só, como primazia fálica instaurada no mundo através do símbolo e da Lei.

Portanto, basta à criança ser o falo, objeto suficiente para satisfazer o desejo materno, trazendo a observação de que, nesse primeiro tempo do Édipo, a relação da criança não é com a mãe, mas com o desejo de quem ocupa essa função, seja homem ou mulher. Esse desejo 
permite que o bebê se situe como assujeitado aos caprichos de quem depende, oferecendo o falo sob a forma de sua imagem:

O que cabe compreender é que esse desejo de desejo implica que estejamos lidando com o objeto primordial que é a mãe, com efeito, e que a tenhamos constituído de tal maneira que seu desejo possa ser desejado por um outro desejo, o do filho, nomeadamente (Lacan, 1958/1999, p.205).

Desde a origem, há uma motivação da ordem do desejo em sua relação fundamental com a ausência do objeto. Antes mesmo de aprender a falar ou compreender o que é dito, já existe a simbolização introduzida pela carência do objeto que completaria o humano, levando a significação a se furtar, a deslizar como um objeto metonímico. Daí o falo representar, ou induzir, o objeto faltante para o plano imaginário.

No entanto, essa dependência do Outro é o que também permite a passagem para o nível dialético da privação, pois os objetos não só dependem desse alguém, como não há amor a dar que seja suficiente para apaziguar um ser que, originalmente, por estrutura, encontra-se desamparado, como o bebê humano. O que ela quer? Por que ainda se vai, já que me ofereço a ela? Quem tem o que ela deseja? A oferta da criança não é mais suficiente, e alguém deve ter o que o agente materno deseja: alguém que se torna um rival no nível imaginário.

Essa falta, marcada na origem, revela que o Nome-do-Pai, como significante que confere autoridade à Lei, já está, no interior do Outro da linguagem, impresso como um significante essencial, que nesse vaivém entre mensagem e código representa no Outro o Outro, como aquele que dá alcance à interdição, uma vez que

[...] a dimensão do Outro como lugar do depósito, do tesouro do significante, comporta, para que ele possa exercer plenamente sua função de Outro, que ele tenha também o significante do Outro como Outro. Também o Outro tem, além dele, esse Outro capaz de dar fundamento à lei. Essa é uma dimensão que, é claro, é igualmente da ordem do significante, e que se encarna em pessoas que tenham essa autoridade (Lacan, 1958/1999, p. 162).

A interdição aqui se caracteriza como um 'não' para o representante do Outro - a mãe. Trata-se de um 'não reintegrarás o teu produto', intervenção que a priva de um objeto simbólico, o falo, que ela possui sob a forma do filho. Esse impedimento remete o capricho materno a uma Lei, Lei que não é dela, mas de um Outro, aquele que possui o objeto de seu desejo.

O pai desse segundo tempo do Édipo, suporte da Lei, é mediado pela mãe, responsável por instaurá-lo como aquele que faz Lei. Logo, é a mãe que deve fundar o pai como mediador daquilo que está para além de seu capricho; ou, dito de outro modo, o pai deve estar presente na palavra da mãe. A essência desse tempo não está apenas no enigmático vaivém do agente materno, mas como Lacan nos adverte, é preciso que exista, por trás dessa função, "[...] toda a ordem simbólica de que ela depende, e a qual, como está sempre mais ou menos presente, permite um certo acesso ao objeto de seu desejo" (Lacan, 1958/1999, p. 189), objeto privilegiado na ordem simbólica - o falo.

O que se torna relevante entendermos é que a matriz do Édipo está inscrita para todos os humanos, não podendo ser apagada. O Outro, como tesouro do significante, comporta que ele também tenha esse Outro capaz de dar fundamento à Lei, trazendo ao filho o reflexo do significante essencial: o Nome-do-Pai. Só assim a castração materna terá efeito sobre o sujeito, revelando que o Outro é privado do objeto tanto quanto o bebê, acarretando uma dupla decepção imaginária que, ao mesmo tempo, confere ao objeto fálico sua importância, uma vez que falta. A privação, portanto, é um confronto com o real da falta, pois nessa 
relação primordial com o Outro da linguagem algo fica de fora, das Ding, a Coisa, núcleo do inconsciente que, embora impossível de representar, por não passar pelo significante, é a própria condição do inconsciente.

Dito de outro modo, no aparelho psíquico há um registro simbólico, um significante essencial que esvazia o gozo puro e introduz a libido a partir da relação com o Outro, marcando possibilidades de satisfação mais-além da descarga da pulsão de morte, tal como verificamos no capítulo anterior desta tese. Trata-se de um ganho advindo de uma perda, aspecto da ordem simbólica que, embora decepcionante, dá acesso às substituições.

Dessa forma, a função do falo, pela via imaginária, embora prometesse certo apaziguamento ao bebê, acaba escapando, pois o desejo não se encerra na imagem, pelo contrário: o falo encarna-se justamente naquilo que falta à imagem, apontando um furo entre a imagem oferecida ao Outro e o desejo do Outro, que protege, pois se trata de um jogo de engodo, onde a criança se oferece ao Outro ao mesmo tempo em que se defende do devoramento do Outro.

O pai desse segundo tempo é desvelado quando a criança encontra a privação no Outro. O pai aparece como projeção da hostilidade do próprio bebê, que retorna a ele, imaginariamente, como um rival, vinculando um primeiro aparecimento da impossibilidade de fazer Um e permitindo que a criança se desvincule de sua identificação com o falo:

Em outras palavras, é na medida em que o objeto do desejo da mãe é tocado pela proibição paterna que o círculo não se fecha completamente em torno da criança e ela não se torna, pura e simplesmente, o objeto do desejo da mãe (Lacan, 1958/1999, p.210).

Para isso, é necessário que a criança aceite a privação do falo materno, levando à percepção de que ela própria não é o único objeto do desejo da mãe: uma dupla decepção imaginária que caracteriza a falta real de um objeto simbólico, permitindo a passagem para o terceiro tempo do Édipo:

Mas por que o pai? A experiência prova que a mãe também o faz tão bem quanto ele. Lembrem-se da observação do pequeno Hans, onde é a mãe quem diz: - Ponha isso para dentro, isso não se faz. Em geral, na maioria das vezes, é a mãe quem diz: - Se você continuar a fazer isso, vamos chamar o doutor para cortá-lo fora. Convém, portanto, assinalar que o pai, na medida em que proíbe no nível da pulsão real, não é muito essencial (Lacan, 1958/1999, p.178).

É nessa etapa que o falo volta a assumir o lugar do significante: falo simbólico - $\Phi$ maiúsculo - que inscreve o gozo perdido. A mensagem, para a criança, chega como um 'não há o que me ofereça que seja suficiente', insatisfação fundamental experimentada pelo agente materno na relação mãe-criança, sendo a função paterna o único recurso para solucionar esse novo impasse. Diante do que era uma completude fálica, a falta se instaura como incompletude do Outro, abrindo o caminho para o terceiro tempo do Édipo, onde a falta do falo é ratificada, já que ninguém o tem.

Neste ponto, fica novamente claro que não importa se o representante da função materna é um homem ou uma mulher, pois a falta está elevada ao nível significante, uma vez que a privação paterna incide sobre um objeto que nem sequer a mãe tem, já que a priva "[...] de algo que só tem existência como símbolo" (Lacan, 1958/1999, p.191), não requerendo sequer, para isso, que o pai exista no ambiente.

O Nome-do-Pai é uma metáfora da presença do pai, que entra em jogo no terceiro tempo como potência paterna; aquele que é suposto ter o objeto do desejo materno, podendo dar esse objeto, e não apenas privando o Outro dele. Aqui a metáfora paterna "[...] leva à 
instituição de alguma coisa que é da ordem do significante, que fica guardada de reserva, e cuja significação se desenvolverá mais tarde" (Lacan, 1958/1999, p.201).

Deixemos claro que, nesse momento da castração, o pai simbólico é um lugar que o agente da função materna aponta como sustentáculo do Nome-do-Pai, puro semblant capaz de produzir uma báscula que reinstaura o falo como objeto do desejo, não importando se esse pai é uma personagem da família, um trabalho, um homem ou mesmo uma mulher, contanto que sustente a impossibilidade de fazer Um. Trata-se de algo estrutural que não se reduz à composição familiar de algum tipo, onde o que está em jogo é a falta, que aponta o desejo materno para além do filho, algo ou alguém que marque um limite a esse sujeito que exerce a função de mãe, convertendo o objeto para sempre perdido em objeto causa do desejo.

O que o pai potente transmite é o falo como significante da falta, motor do desejo que dá possibilidade de significação ao enigma do desejo materno. Essa metáfora revela no Outro o lugar da Lei como tal, do significante essencial que traz sentido ao que antes era enigma.

\section{$\underline{\mathrm{NP}} \cdot \underline{\mathrm{DM}} \rightarrow \mathrm{NP}(\mathrm{A} / \Phi)$}

NP - Significante Nome-do-Pai
DM - Desejo da mãe
X - Significação desconhecida para o sujeito
A - Outro
$\Phi$ - Falo

A função paterna, ao operar como metáfora, substitui o desejo obscuro da mãe - puro capricho sem Lei -, pelo Nome-do-Pai, símbolo da ausência da mãe, permitindo que o sujeito saia do impasse imaginário. Desde então, o Nome-do-Pai "vetor de uma encarnação da Lei no desejo" (Lacan, 1969/2003, p.373), ao marcar a falta simbólica do objeto imaginário, o falo, também revela a carência de um objeto harmônico que complete, e a ausência de um significante que represente o sujeito de forma absoluta; hiância inerente à relação do sujeito com o Outro, indicada pela impossibilidade de plenitude.

Assim, esse terceiro tempo, que equivale ao declínio do complexo de Édipo, é marcado pela simbolização da Lei e pela renúncia ao gozo. O pai, antes na condição de falo rival junto à mãe, onipotente, passa a ser reconhecido como castrado: ele também não tem o falo, mas tem alguma coisa com o valor de dom.

Portanto, embora a falta seja um dado de estrutura, é somente no terceiro tempo que ganha significação, revelando que tanto o pai quanto a mãe e o filho não são e não têm o falo, falta radical que, por retroação, revela a falta-a-ser a partir da falta-a-ter, produzida pela inclusão do sujeito na linguagem. Logo, frustração - ser ou não ser o falo -, privação - ter ou não ter o falo -, e castração - ter ou não ter o dom -, são os três tempos lógicos da transmissão da falta, revelando que o que é desejado é o impossível.

Em outras palavras, é a Lei da interdição do incesto que regulamenta as trocas humanas, pois, a partir da castração, a falta deixa de ser um vazio a ser preenchido, sendo elevada à categoria de vetor do desejo, motor psíquico das buscas futuras. Por isso, os objetos imaginários, embora postos no lugar do que falta, não promovem completude, não recuperam o gozo perdido; condição dada pelo falo simbólico que, ao permitir as infinitas substituições, ampliando o circuito de trocas, mantém o impossível da relação sexual.

A partir de então, o objeto a, como resto dessa operação, aquilo que falta e promete o resgate, fará a ponte entre o sujeito e o outro, causando o desejo: lógica da retroação que eleva os objetos a ao lugar do falo faltante.

\section{a}


Por este motivo, em $O$ Seminário, Livro 22: R.S.I., Lacan acrescenta a père-version como a orientação do desejo de um sujeito para o objeto que o causa. Ou seja, o representante da função do pai, ao tomar o(a) parceiro(a) representante da função da mãe como causa de desejo - a - aponta para um limite no campo materno, retirando-o(a) do lugar de sujeito - \$ que coloca o filho como objeto de seu gozo, a:

Um pai só tem direito ao respeito, senão ao amor, se o-dito amor, o-dito respeito, estiver, vocês não vão acreditar em suas orelhas, père-vertidamente orientado, isto é, feito de uma mulher, objeto pequeno a que causa seu desejo [...], única garantia de sua função de pai (Lacan, 1975/ inédito], p.23).

Portanto, é no lugar de objeto de desejo que o representante da função materna pode remeter o filho ao pai, aquele que, do lugar de sujeito, se defronta com o objeto de seu gozo $\$ \rightarrow a-$, ratificando a falta de simetria nesse encontro:

FUNÇÃO MATERNA

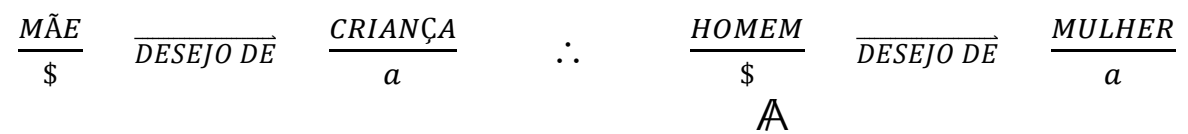

Retomemos então às questões colocadas inicialmente, a fim de concluir: como conceber que a anatomia do sujeito que exerce a função materna ou a função paterna possa acarretar à criança a impossibilidade de subjetivação de seu sexo quando a cultural distinção de papéis ideais, que fazem da mulher uma mãe, e do homem um pai, não condiz com certos arranjos familiares?

Inicialmente, temos como um dado da estrutura simbólica, presente no mundo, a pura manifestação do par presença-ausência. Nesse marco zero, não há outro, seja homem ou mulher. Em seguida, no primeiro tempo do Édipo, a função materna, onipotente, diz respeito ao Outro da linguagem, que dá ou não acesso aos objetos, trazendo o dom, enquanto o pai aparece velado, embora a metáfora paterna opere por si só, como primazia fálica instaurada no mundo através do símbolo e da Lei.

No segundo tempo do Édipo, a função paterna não está menos velada que no primeiro tempo, mas marca sua presença como suporte da Lei. Essa mensagem retorna para a criança através da mediação do discurso materno, revelando a insuficiência do que é oferecido pelo filho no que tange à completude, permitindo a passagem para o terceiro tempo da relação, quando o Outro da linguagem aparece privado, desejante, e a função paterna nasce revestida como símbolo. O pai, que também não tem o falo, é tomado como aquele que tem alguma coisa com valor de dom, permitindo ao assujeitado o acesso ao desejo. Logo:

$\varphi$ - o falo imaginário revela-nos o assujeitamento da criança, a alienação imaginária devida à identificação ao falo materno, objeto que supostamente falta à mãe.

$\Phi$ - o falo simbólico, significante do desejo, tomado como símbolo, é o operador lógico no discurso do inconsciente.

$-\varphi$ - o falo imaginário negativado desvenda o objeto faltante, objeto imaginário da castração na articulação com o desejo, que vela a falta do significante.

Assim, a criança, num primeiro momento, mantém uma relação não com a mãe, mas com o desejo de quem exerce essa função, causa da fenda necessária para que se posicione como falo imaginário do Outro. Depara-se, em seguida, com um além, constituído pela relação desse Outro com a Lei, que protege a criança do devoramento. Por fim, o falo, antes no plano imaginário, retorna ao plano simbólico pela via da metáfora paterna, de onde a criança reconhece não sê-lo e não tê-lo, levando-nos a concluir que não há falo imaginário 
sem falo simbólico, uma vez que, como seres de linguagem, o significante essencial, o Nomedo-Pai, está desde sempre presente, impondo um limite, uma impossibilidade, e oferecendonos acesso à Lei, desde que saibamos servir-nos dele.

De tal modo, seja pelo lado da força ou da fraqueza, o pai tornar-se-á preferível à mãe, estabelecendo a identificação final do complexo de Édipo no nível do Ideal de Eu, onde está centrada a diferença do efeito do complexo de castração no menino e na menina. Uma vez reconhecido não ter, o menino aceita não ter aquilo que tem e a menina aceita não ter aquilo que realmente não tem. Para tê-lo, é preciso que seja instaurado que não se pode tê-lo, de modo que a possibilidade de ser castrado torna-se essencial na assunção da posição sexuada:

É isso que escandaliza aqueles que gostariam que a situação concernente ao objeto sexual fosse simétrica em ambos os sexos. Assim como o homem tem que descobrir e, depois, adaptar a uma série de aventuras o uso de seu instrumento, o mesmo deveria acontecer com a mulher, isto é, que o cunnus ficasse no centro de toda a sua dialética. Mas não é nada disso, e foi precisamente essa a descoberta da análise (Lacan, 1958/1999, p.207).

O falo, como ausência para ambos os sexos, por ser um significante do desejo cujo significado escapa, não subjetivável na sexualidade, tanto conota o sujeito como faltoso e desejante quanto confere ao objeto perdido um brilho fálico. Daí uns sustentarem tê-lo e outros sustentarem não tê-lo; diversidades psíquicas que surgem do irremediável da diferença dos sexos.

\section{Notas}

(1) A carta foi retirada da obra Bismarck, the Man and the Statesman, datada de 1898. Tratase de Otto von Bismarck (1815-1898), chanceler da Alemanha.

(2) O desejo da criança é despertado pelo objeto de desejo do Outro: o falo.

(3) Aqui não se trata da função do pai real, mas de um dado inerente a qualquer reprodução: o espermatozoide, tal como Lacan desenvolve em O Seminário, Livro 17: o avesso da psicanálise. "O pai real nada mais é que um efeito de linguagem, e não tem outro real. [...] Só há um pai real, é o espermatozoide, e, até segunda ordem, ninguém jamais pensou em dizer que é filho de tal espermatozoide. [...] Mas isso é completamente novo, e não tem absolutamente nada a ver com tudo o que se enunciou até aqui como sendo a função do pai" (LACAN, 1970/1992, p. 120). Ver Do mito à estrutura. In: O Seminário, Livro 17: o avesso da psicanálise, 1992.

\section{Referências}

Alberti, S. (coord.). (2006). As realidades sexuais e o inconsciente: histórico da questão. Bahia: EPFCL-Brasil.

Alberti, S. (org.). (2008). A sexualidade na aurora do século XXI. Rio de Janeiro: Cia de Freud.

Conté, C. (1995). O real e o sexual: de Freud a Lacan. Rio de Janeiro: Jorge Zahar.

Eribon, D. (2008). Reflexões sobre a questão gay. Rio de Janeiro: Companhia de Freud.

Ferreira, N. P. (2004). A teoria do amor. Rio de Janeiro: Jorge Zahar.

Fink, B. (1998). O sujeito lacaniano: entre a linguagem e o gozo. Rio de Janeiro: Jorge Zahar. 
Freud, S. (2007). La interpretación de los sueños. Em Obras completas: La interpretación de los sueños: segunda parte. Buenos Aires: Amorrortu. v. V (Original publicado em 19001901).

Freud, S. (2008). Tres ensayos de teoria sexual. Em Obras completas: Fragmento de análisis de un caso de histeria (Dora), Tres ensayos de teoria sexual y otras obras. Buenos Aires: Amorrortu v. VII (Original publicado em 1905).

Freud, S. (2007). Sobre las teorías sexuales infantiles. Em Obras completas: El delirio y los sueños en la Gradiva de W. Jensen y otras obras. Buenos Aires: Amorrortu v. IX (Original publicado em 1908).

Freud, S. (2008). Análisis de la fobia de un niño de cinco años. Em Obras completas: Análisis de la fobia de un niño de cinco años: el pequeño Hans, A propósito de un caso de neurosis obsesiva: el hombre de las ratas. Buenos Aires: Amorrortu. v. X. (Original publicado em 1909).

Freud, S. (2007). Un recuerdo infantil de Leonardo da Vinci. Em Obras completas: Cinco conferencias sobre psicoanálisis, Un recuerdo infantil de Leonardo da Vinci y otras obras. Buenos Aires: Amorrortu. v. XI. (Original publicado em 1910).

Freud, S. (2007). La organización genital infantil: una interpolación en la teoria de la sexualidad. Em Obras completas: El yo y el ello y otras obras. Buenos Aires: Amorrortu. v. XIX. (Original publicado em 1923).

Freud, S. (2007). El sepultamiento del complejo de Edipo. Em Obras completas: El yo y el ello y otras obras. Buenos Aires: Amorrortu. v. XIX. (Original publicado em 1924).

Freud, S. (2007). Algunas consecuencias psíquicas de la diferencia anatómica entre los sexos. Em Obras completas: El yo y el ello y otras obras. Buenos Aires: Amorrortu. v. XIX. (Original publicado em 1925).

Freud, S. (2007). Fetichismo. Em Obras completas: El porvenir de una ilusión, El malestar en la cultura y otras obras. Buenos Aires: Amorrortu. v. XXI. (Original publicado em 1927). Jorge, M. A. C. (2005). Fundamentos da Psicanálise de Freud a Lacan, volume 1: as bases conceituais. Rio de Janeiro: Jorge Zahar.

Jorge, M. A. C. (2007). A teoria freudiana da sexualidade 100 anos depois (1905-2005). Em Psychê. São Paulo, ano 11, n. 20, p. 29-46.

Jorge, M. A. C. (2010). Fundamentos da Psicanálise de Freud a Lacan, volume 2: a clínica da fantasia. Rio de Janeiro: Jorge Zahar.

Lacan, J. (1995). O Seminário, Livro 4: a relação de objeto. Rio de Janeiro: Jorge Zahar. (Original publicado em 1956-57).

Lacan, J. (1999). O Seminário, Livro 5: as formações do inconsciente. Rio de Janeiro: Jorge Zahar. (Original publicado em 1957-58).

Lacan, J. (1998). A significação do falo. Em Escritos. Rio de Janeiro: Jorge Zahar. (Original publicado em 1958).

Lacan, J. (2003). Nota sobre a criança. Em Outros Escritos. Rio de Janeiro: Jorge Zahar. (Original publicado em 1969).

Lacan, J. (1992). O Seminário, Livro 17: o avesso da psicanálise. Rio de Janeiro: Jorge Zahar. (Original publicado em 1970).

Lacan, J. (1985). O Seminário, Livro 20: mais, ainda. Rio de Janeiro: Jorge Zahar. (Original publicado em 1972-73).

Lacan, J. (inédito). O Seminário, Livro 22: RSI. (Original publicado em 1974-75).

Marques, L. (2008). Homossexualidade: uma análise do tema sob a luz da psicanálise.

Dissertação (Mestrado em Psicanálise, Saúde e Sociedade) - Universidade Veiga de Almeida, Rio de Janeiro.

Marques, L. (2016). Homossexualidade e Ética Psicanalítica. Tese (Doutorado em Psicanálise) - Universidade do Estado do Rio de Janeiro, Rio de Janeiro. 
Quinet, A. \& Coutinho Jorge, M. A. (orgs.). (2013). As Homossexualidades na Psicanálise: na história de sua despatologização. São Paulo: Segmento Farma.

Rabinovich, D. S. (2005). A significação do falo: uma leitura. Rio de Janeiro: Companhia de Freud.

Safouan, M. (1979). Estudos sobre o Édipo: introdução a uma teoria do sujeito. Rio de Janeiro: Jorge Zahar.

Citação/Citation: Jorge, M.A.C. e Marques, L. (2016). O complexo de Édipo e a função fálica: sobre a criação de filhos por casais homoparentais. Trivium: Estudos Interdisciplinares (ano VIII, v.2), p. 143-155.

Recebido em: 28/09/2015

Aprovado em: 15/12/2015 